\title{
AROMATIC PLANTS OF BANGLADESH : ESSENTIAL OILS OF LEAVES AND FRUITS OF LITSEA GLUTINOSA (LOUR.) C.B. ROBINSON
}

\author{
Jasim Uddin Chowdhury, Md. NAzRUl Islam Bhuiyan* \\ AND Nemai ChandRa NANDi \\ BCSIR Laboratories, P.O. Chittagong Cantonment, Chittagong-4220, Bangladesh
}

Key words: Litsea glutinosa, Essential oil, GC-MS, Phytol, Lauric acid

\begin{abstract}
The volatile oil constituents of leaf- and fruit in Litsea glutinosa (Lour.) C.B. Robinson, identified by GC-MS analysis, was 83 and 33, respectively. The major constituents of leaf were phytol $(22.42 \%)$, caryophyllene $(21.48 \%)$, thujopsene $(12.17 \%)$ and $\beta$-myrcene $(5 \%)$; while those of the fruit oil contained lauric acid (44.84\%), 3-octen-5-yne, 2,7-dimethyl (28.72\%), $\alpha$-cubebene (6.84\%) and caryophyllene $(5.04 \%)$.
\end{abstract}

Litsea glutinosa (Lour.) C.B. Robinson belongs to the family Lauraceae and is a well-known evergreen species growing wild in the forest of Chittagong and Sylhet districts in Bangladesh. It is occasionally planted in most areas of the country (Ghani 2003). The plant can attain a height of 20 meters. Prior to a decade or two, L. glutinosa hardly had any commercial significance to the people but now this plant is used for some therapeutic purposes at domestic level (Saxena and Brahmam 1995). Leaves are mucilaginous and considered for antispasmodic, emollient, and poultice. The leaves are also used in diarrhoea and dysentery as well as in wounds and bruises (Ghani 2003). The leaves were reported for the treatment of the spontaneous and excessive flow of semen in young boys (Kirtikar and Basu 1981). The leaf extract also shows antibacterial and cardiovascular activities (Kar et al. 1970, Kar and Jain 1971, Chomkamon et al. 2000). The berries yield oil which is used by some tribal practitioners in the treatment of rheumatism. The extraction is difficult and the yield is very low, hence the oil is costly and less commonly used. Tannin, $\beta$-sitosterol, and actinodaphnine are reported to be the common constituents of the species; and other constituents known are : Boldine, norboldine, laurotetanine, n-methyllaurotetanine, n-methylactinodaphnine, quercetin, sebiferine, litseferine etc. (Chatterjee and Pakrashi 1994). The essential oils of green and black fruits contained more than 40 and 30 compounds, respectively. Unripe and ripe fruit essential oils were characterized by a high proportion of (E)- $\beta$-ocimene, 70.8 and $84.1 \%$, respectively. Predominant minor constituents of these oils were caryophyllene oxide 5 and $0.9 \%$, respectively, $\beta$-caryophyllene (3.4 and $4.3 \%$, respectively) and (Z)- $\beta$-ocimene, 1.8 and 2.1\%, respectively (Choudhury et al. 1996, Chomkamon et al. 2000). Earlier, similar work was also carried out (Chowdhury et al. 2007). In here, the chemical composition of the leaf and fruit oils of L. glutinosa harvested from Chittagong regions of Bangladesh has been reported.

The essential oil from leaves and fruits of L. glutinosa were extracted by hydrodistillation method for $4 \mathrm{hrs}$ from plants grown in BCSIR Laboratories compound, Chittagong during June 2007.

The essential oils from leaves and fruits of L. glutinosa were analyzed by GC-MS electron impact ionization method on GC-17A gas chromatograph (Shimadzu) coupled with a GC-MS QP 5050A Mass Spectrometer (Shimadzu); using fused silica capillary column $(30 \mathrm{~m} \times 2.5 \mathrm{~mm} ; 0.25$ $\mu \mathrm{m}$ film thickness), coated with DB-1 (J\&W); injector temperature $220^{\circ} \mathrm{C}$, detector temperature $250^{\circ} \mathrm{C}$, oven temperature 60 to $250^{\circ} \mathrm{C}\left(3^{\circ} \mathrm{C} / \mathrm{min}\right)$, column temperature initially at $100^{\circ} \mathrm{C}(2 \mathrm{~min})$ to

*Corresponding author. E-mail: Nazrul119@yahoo.com 
rise up to $250^{\circ} \mathrm{C}$ final at the rate of $3^{\circ} \mathrm{C} / \mathrm{min}$ for $50 \mathrm{~min}$; carrier gas, helium, at constant pressure of $90 \mathrm{Kpa}$. Acquisition parameters full scan; scan range 40-350 amu. The compounds were identified by comparing with the NIST (National Institute of Standards and TechnologyChemistry) library data.

The volatile compounds identified in the leaf and fruit oils of $L$. glutinosa from Bangladesh were 83 and 33, respectively of which 14 and 7 most prevalent ones are listed in Table 1. The relative content of volatile components in the total peak area of leaf and fruit were 96.85 and $99 \%$, respectively.

Table 1. Constituents of leaf and fruit essential oils of $L$. glutinosa.

\begin{tabular}{|c|c|c|c|}
\hline $\begin{array}{l}\text { Major constituents } \\
\text { of leaf oil }\end{array}$ & $\begin{array}{l}\text { Leaf oil } \\
(\%)\end{array}$ & $\begin{array}{l}\text { Major constituents } \\
\text { of fruit oil }\end{array}$ & $\begin{array}{l}\text { Fruit oil } \\
\qquad(\%)\end{array}$ \\
\hline & & $\begin{array}{l}\alpha \text {-cubebene } \\
\text { (E)-ocimene } \\
\text { 3-octen-5-yne, 2,7-dimethyl }\end{array}$ & $\begin{array}{c}6.48 \\
2.24 \\
28.72\end{array}$ \\
\hline $\begin{array}{l}\alpha \text {-muurolene } \\
\beta \text {-myrcene } \\
\alpha \text {-phellandrene } \\
\beta \text {-pinene }\end{array}$ & $\begin{array}{c}2.33 \\
5 \\
1.40 \\
1\end{array}$ & & \\
\hline $\begin{array}{l}\text { Caryophyllene } \\
\text { Cinnamyl acetate } \\
\text { Cyclohexanol, 2-methylene- } \\
\text { 5-(1-methylethenyl)- } \\
\text { Diepi-. } \alpha \text {-cedrene epoxide } \\
\text { Limonene }\end{array}$ & $\begin{array}{l}21.48 \\
1.97 \\
2.09 \\
\\
2.79 \\
3.19\end{array}$ & Caryophyllene & 5.04 \\
\hline $\begin{array}{l}\text { n-hexadecanoic acid } \\
\text { Phytol }\end{array}$ & $\begin{array}{c}1.12 \\
22.42\end{array}$ & $\begin{array}{l}\text { Lauric acid } \\
\text { n-hexadecanoic acid }\end{array}$ & $\begin{array}{c}44.84 \\
3.02\end{array}$ \\
\hline $\begin{array}{l}\text { tau.-cadinol } \\
\text { Thujopsene } \\
\text { Z-ocimene }\end{array}$ & $\begin{array}{c}1.81 \\
12.17 \\
2.24\end{array}$ & Oleic acid & 2.16 \\
\hline
\end{tabular}

Results showed that the oils were complex mixture of numerous compounds; many of which were present in trace amounts. It is worth mentioning here that there is a great variation in the chemical composition of leaf and fruit oils of L. glutinosa. Phytol is the main component in L. glutinosa leaf but totally absent in its fruit. On the other hand, fruit oil contains lauric acid but totally absent in its leaf oil. $\alpha$-pinene, $\beta$-pinene, sabinene, camphene, limonene, (E)-ocimene, eugenol , nhexadecanoic acid, oleic acid were observed as the nine versatile common compounds present in both the oils with variations in their content (Table 1 ). On the basis of above study it may be concluded that L. glutinosa, growing widely in Bangladesh, may be utilized as a source for the isolation of natural phytol and lauric acid.

\section{References}

Chatterjee, A. and S. Pakrashi. 1994. The Treatise of Indian Medicinal Plants.Vol. I, INSA, New Delhi, India. pp. 107.

Chomkamon, U., S. Nongluksna, De-E, Wanchai and R. Nijsiri. 2000. Chemical composition and antimicrobial activity of essential oils from plants in Litsea spp. Technical information services (TIS)/MUTT. pp. 18-20. 
Choudhury, S.N., R.S. Singh, A.C. Ghosh and P.A. Leclerco. 1996. Litsea glutinosa (Lour.) C.B.Rob., a new source of essential oil from northeast India. J. Eessentl. Oil Res. 8(8): 553-556.

Chowdhury, J.U., N.C. Nandi and M.N. I. Bhuiyan. 2007. Chemical composition of leaf essential oil of Lantana camara L. from Bangladesh. Bangldesh J. Bot. 36(2):193-194.

Ghani, A. 2003. Medicinal plants of Bangladesh: Chemical constituents and uses, Asiatic Society of Bangladesh, Nimtali, Dhaka-1000, pp. 285.

Kar, A, M.K. Menon and C.S. Chauhan. 1970. Effect of essential oil of Litsea glutinosa (Lour.) C. B. Robinson on cardiovascular system and isolated tissues. Indian J Exp Biol. 8(1): 61-62.

Kar, A. and S.R. Jain. 1971. Antibacterial evaluation of some indigenous medicinal volatile oils. Plant Foods for Human Nutrition 20(3): 231-237.

Kirtikar, K. and B. Basu. 1981. Indian Medicinal Plants (revised issue), Vol.III, Allahabad. pp. 2156-61.

Saxena, H. and M. Brahmam. 1995. The Flora of Orissa, Vol. III, Basundhara, Bhubaneswar, India. pp. 1- 5.

(Manuscript received on 28 November, 2007; revised on 19 January, 2008) 